\title{
Effect of $\mathrm{K}^{+}$and Salicylic Acid on Broccoli (Brassica oleraceae var. Italica) Plants Grown Under Saline Water Irrigation
}

\author{
Zohair Mahmoud Mirdad ${ }^{1}$ \\ ${ }^{1}$ Department of Arid Land Agriculture, Faculty of Meteorology, Environment, and Arid Land Agriculture, King \\ Abdulaziz University, Jeddah, Saudi Arabia \\ Correspondence: Zohair Mahmoud Mirdad, Department of Arid Land Agriculture, Faculty of Meteorology, \\ Environment, and Arid Land Agriculture, King Abdulaziz University, P. O. Box 6551, Jeddah 21452, Saudi \\ Arabia. Fax: 966-12-688-5612. E-mail: zmirdad1@yahoo.com
}

Received: June 3, 2014 Accepted: July 23, 2014 Online Published: September 15, 2014

doi:10.5539/jas.v6n10p57 URL: http://dx.doi.org/10.5539/jas.v6n10p57

\begin{abstract}
High salinity affects plant growth and productivity of most vegetable crops through osmotic effects which inhibition of water uptake by roots or specific ion effects and causes toxicity of salt ions, as well as changes in soil physical and chemical properties causing a decrease in the growth of the roots and plants. This research conducted to improve the agricultural practices of broccoli production by using the $\mathrm{K}^{+}$and salicylic acid (SA); which will contribute to overcome the deleterious effect of salinity stress. The results of this study showed that broccoli plants grown under saline water that receiving $\mathrm{K}^{+}$at concentration $1000 \mathrm{mg} \mathrm{l}^{-1}$ as foliar application were recorded minimum the deleterious impacts of salinity stress and achieved maximum plant height, number of leaves and branches, leaf area per plant, the main, secondary and total curd yield $\left(\mathrm{t} \mathrm{ha}^{-1}\right)$ and water use efficiency (WUE) over control treatment. Furthermore, the curd diameter (of main and secondary), curd weight (of main, secondary and plant) dry matter percentage of the curds and the leaf and curd mineral contents (N, P and K\%) were improved with foliar application of $\mathrm{K}$ up to $1000 \mathrm{mg} \mathrm{l}^{-1}$. Moreover, the vegetative growth, cruds yield and its quality, WUE and leaf and crud mineral contents of broccoli plants irrigated with saline water increased significantly and successively as the SA concentration was increased up to $200 \mathrm{mg} \mathrm{l}^{-1}$. The combined foliar application of $1000 \mathrm{mg} \mathrm{l}^{-1} \mathrm{~K}^{+}$with salicylic acid at $200 \mathrm{mg} \mathrm{l}^{-1}$ as a dernch and foliar application is the most efficient combination treatment, which gave the best results to alleviate the deleterious impact of salinity stress on the vegetative growth, curd yield and its quality characters, leaf and curds chemical contents of broccoli plants irrigated with saline water.
\end{abstract}

Keywords: curd yield of broccoli, growth, potassium, salicylic acid, saline water, water use efficiency

\section{Introduction}

Broccoli (Brassica oleraceae var. Italica) is grown for its edible curd, which has become a popular item in the kitchen because of its high nutritive and medicinal values (Feher, 1986). Where, it is a good source of vitamins $\left(\mathrm{A}, \mathrm{B}_{1}, \mathrm{~B}_{2}, \mathrm{~B}_{5}, \mathrm{~B}_{6}, \mathrm{C}, \mathrm{E}\right.$ and folic acid), minerals $(\mathrm{Ca}, \mathrm{Mg}, \mathrm{Zn}$, and $\mathrm{Fe}$ ), carotenoids, fiber, and antioxidant substances, which prevent the formation of cancer causing agents (Beecher, 1994; Michaud et al., 2002). Eating more than one serving of broccoli a week reduces the risk of prostate cancer by up to $45 \%$ (Gad \& Abd El-Moez, 2011). Therefore, it is fast becoming an important fresh market and processing vegetable crops in many parts of the world (Morelock et al., 1982).

In Saudi Arabia, high temperatures, low quality of irrigation water and soil salinity are major limiting factors in sustaining and increasing vegetable productivity. Whereas, hot and dry environment, high evapotranspiration results in substantial water loss, thus leaving salt around the plant roots which interfere with the plant's ability to uptake water particularly with the drip irrigation system. High salinity affects plant growth and productivity of vegetable crops through osmotic effects (Yamaguchi \& Blumwald, 2005), which inhibition of water uptake by roots or specific ion effects (Yildirim et al., 2008). Addition, salinity imposes causes toxicity of salt ions, and changes in soil physical and chemical properties (Keren, 2004), as well as causing an imbalance of nutritional cations in plant tissues resulting from altered $\mathrm{K}^{+} / \mathrm{Na}^{+}$ratios $(\mathrm{Gad}, 2005)$ and leads to a buildup in $\mathrm{Na}^{+}$and $\mathrm{Cl}^{-}$ concentrations that are detrimental to plants (Yamaguchi \& Blumwald 2005). Where, salinity has been shown to affect the directly nutrient uptake as $\mathrm{Na}^{+}$reducing $\mathrm{K}^{+}$and $\mathrm{Ca}^{2+}$ uptake (Yildirim et al., 2006) or by $\mathrm{Cl}^{-}$a reducing 
NO3 $^{-}$uptake (Halperin et al., 2003). One of the effective practices to mitigate the deleterious effects of salinity stresses and inducing salt tolerance in many crops under arid region conditions is the use of salicylic acid (El-Tayeb, 2005; Gunes et al., 2005; Stevens et al., 2006) and potassium (Yildirim et al., 2009; Khan et al., 2013) as a foliar application through their contribution in alleviating $\mathrm{Na}^{+}$and $\mathrm{Cl}^{-}$injury.

Potassium is one of the essential elements in the nutrition of the plant. However, under the salinity stress, metabolic toxicity of $\mathrm{Na}$ is largely due to its ability to compete with $\mathrm{K}$ for binding site essential for cellular function (Bhandal \& Malik, 1988). Many studies have revealed that $\mathrm{K}^{+}$alleviates the adverse effects of salinity on plant growth by regulating the desirable $\mathrm{K} / \mathrm{Na}$ ratio (Marschner, 1995). Whereas, a $\mathrm{K}^{+}$foliar application improved nutrient status causing increases in salt tolerance of different plants (El-Fouly et al., 2002; Safaa et al., 2013) by enhancing the biosynthesis of organic metabolites and improving nutritional status (Fathy et al., 2009). Yildirim et al. (2009) reported that the highest alleviation effect of foliar nutrient application at $40 \mathrm{mM}$ salinity stress was observed for $10 \mathrm{mM} \mathrm{KNO}_{3}$; resulting in an increase in plant root dry weight (50\%), shoot dry weight $(50 \%)$ of strawberry plants. Potassium in plants is necessary to increase the efficiency of photosynthesis and use of water (Rose, 2001). Moreover, $\mathrm{K}^{+}$plays an important role in the synthesis of amino acid and protein as well as translocation of sugars and assimilates within the plant and the accumulation of high molecular carbohydrates (Yagodin 1982; Archer, 1985). In addition, it has activate the enzymes involved in biosynthesis of organic acids (Evans \& Sorger, 1996), as well as accelerating translocation of carbohydrate necessary for fruit formation and development (Marschner, 1986) which leads to increase plant growth and yield.

Using salicylic acid (SA) can as an active practice to facilitate the plant growth (Yildirim et al., 2008), where it play an important role in alleviating the deleterious effects of several environmental stresses on plants and which ones high temperature, drought (Singh \& Usha, 2003; Shi et al., 2006) and salinity (Yildirim et al., 2008) stresses Raskin et al. (1990) reported that SA is synthesized by many plants and accumulated in the plant tissues under the impact of unfavorable abiotic factors and contributing to the increase of plant resistance to salinization (Kang $\&$ Saltveit, 2002). Where, SA is an endogenous growth regulator of phenolic nature, which participates in the regulation of physiological processes in plants (Karlidag et al., 2009). Many researchers clarified several beneficial effects of SA under abiotic stress conditions such as; can it play a significant role in plant water relations (Barkosky \& Einhelling, 1993), photosynthesis, growth rate and stomatal regulation (Khan et al., 2003; Arfan et al., 2007), as well as ion uptake and transport (Gunes et al., 2005) and membrane permeability (Barkosky \& Einhellig, 1993). Where, Farahbakhsh and Shamsaddin Saiid (2011) concluded that the positive reaction of the SA application under saline conditions on plant growth may be due to the chemical changes in plants throughout avoiding the uptake of toxic ions $\mathrm{Na}^{+}$and $\mathrm{Cl}^{-}$and enhancing the uptakes of $\mathrm{NO}_{3}^{-}, \mathrm{Mg}^{2+}, \mathrm{Fe}^{2+}$, $\mathrm{Mn}^{2+}$, and $\mathrm{Cu}^{2+}$. Because of multiple roles of $\mathrm{SA}$, it can greatly benefit plant growth under some environmental stresses including high temperature and drought on cucumber, bean, tomato and wheat (Singh \& Usha, 2003; Senaratna et al., 2000; Shi et al., 2006), as well as salinity on tomato, maize and violet (Stevens et al., 2006; Farahbakhsh \& Shamsaddin Saiid, 2011; Hussain et al., 2011). However, Salehi et al. (2011) stated that the effects of SA on physiological processes of plants depend on its concentration, type of plant, the stage of plant growth and environmental conditions.

This work conducted to minimize the deleterious impacts of salinity stress on broccoli (cv. Emperor) plants grown under saline water by using foliar application of salicylic acid and potassium.

\section{Materials and Methods}

This study was carried out at Agricultural Experiment Station, Hada-Alsham, King Abdulaziz University, Saudi Arabia, during the agriculture season of 2012/2013. The experiment included 9 treatments and repeated three times, which were the combinations concentrations of three potassium $\left(\mathrm{K}^{+}\right)$and three salicylic acid (SA; 2-hydroxybenzoic acid).

\subsection{Soil and Irrigation Water Analysis}

Before the beginning of the trial, physical and chemical properties of the experimental site soil $(0-30 \mathrm{~cm})$ were estimated according to the published procedures by (Page et al., 1982). The soil texture is sandy (92.1\% sand, 5.9\% silt and $2.0 \%$ clay) with $\mathrm{pH}=8.1, \mathrm{EC}=3.72 \mathrm{dS} \mathrm{m}^{-1}$ and organic matter $=0.03 \%$. Available soil $\mathrm{N}, \mathrm{P}$ and $\mathrm{K}$ were 19 , 8 and $17 \mathrm{mg} / \mathrm{kg}$, respectively. Chemical properties of irrigation water, which obtained from a local well, were measured (Page et al., 1982). The irrigation water had an EC value of $4.23 \mathrm{dS} \mathrm{m}^{-1}$, and contained $\mathrm{Na}=0.49, \mathrm{Mg}=$ $0.32, \mathrm{Ca}=6.18, \mathrm{HCO}_{3}=0.69, \mathrm{Cl}=1.48$ and $\mathrm{SO}_{4}=6.63 \mathrm{meq} \mathrm{l}^{-1}$.

\subsection{Experimental Design}

The experimental design used was the split-plot system in randomized complete blocks design with three 
replications. The potassium concentrations were, randomly, arranged in the main plots, while three SA concentrations were, randomly, distributed in the sub-plots. Each sub-plot contained two rows having an area of 16 $\mathrm{m}^{2}$. Broccoli (cv. Emperor) seedlings were transplanted into the soil on 14 December 2012. The row spacing was $50 \mathrm{~cm}$ between the seedlings and $120 \mathrm{~cm}$ between the rows. Each sub-plot contained 32 plants. SA solutions at rates; $0,100,200 \mathrm{mg} \mathrm{l}^{-1}$ and $\mathrm{K}^{+}$(potassium sulphate; $\mathrm{K}_{2} \mathrm{SO}_{4}$ ) solutions at rate; 0,500 and $1000 \mathrm{mg} \mathrm{l}^{-1}$, were sprayed on the shoots of broccoli plant at three times, starting from $3^{\text {th }}$ week after transplanting, during late afternoon hours with 10 days intervals using a hand-held sprayer until dripping, with a held atomizer. Moreover, the same concentrations of SA solutions were applied three times, at 10-day intervals, as a drench to the plant root area at rate 0.11 per plant, starting from the $2^{\text {nd }}$ week after transplanting (Senaratna et al., 2000; Stevens et al., 2006). The control plants were treated with tap water.

\subsection{Irrigation and Fertilization}

The actual evapotranspiration of broccoli plant $\left(\mathrm{ET}_{\mathrm{c}}\right)$, under Hada-Alsham region conditions, was calculated and adjusted at the beginning of each growth stage (Table 1) by multiplying reference evapotranspiration $\left(\mathrm{ET}_{0}\right)$ for different months of the growing season (November, 2012 - May, 2013) by a crop coefficient $\left(\mathrm{K}_{\mathrm{C}}\right), \mathrm{ET}_{\mathrm{c}}=\mathrm{ET}_{0} \times$ $\mathrm{K}_{\mathrm{C}}$, as indicated in Allen et al. (1998). The drip irrigation system consisted of laterals GR of $16 \mathrm{~mm}$ in diameter with drippers at $0.5 \mathrm{~m}$ distance. The drippers had a discharge rate $4 \mathrm{l} \mathrm{h}^{-1}$. Irrigation water was applied every alternate day, to maintain soil moisture above $50 \%$ soil moisture depletion, according to Qassim and Ashcroft (2002), which is the optimum level of broccoli plants.

Table 1. Length of the growth stages, crop coefficients $\left(\mathrm{K}_{\mathrm{c}}\right)$, reference evapotranspiration $\left(\mathrm{ET}_{0}\right)$ and water requirements of broccoli crop $\left(\mathrm{ET}_{\mathrm{c}}\right)$, at Hada-Alsham region conditions, Saudi Arabia

\begin{tabular}{llll}
\hline Growth stages & Initiation & Vegetative & Curds formation \\
\hline Number of days per stage & 25 & 40 & 55 \\
Crop Coefficients $\left(\mathrm{K}_{\mathrm{C}}\right)$ & 0.7 & 0.82 & 1.0 \\
Reference evapotranspiration $\left(\mathrm{ET}_{0}\right) \mathrm{mm} \mathrm{day}^{-1}$ & 4.6 & 5.8 & 6.1 \\
Water requirements of broccoli crop $\left(\mathrm{ET}_{\mathrm{c}}\right) \mathrm{mm} \mathrm{day}^{-1}$ & 3.22 & 4.76 & 6.1 \\
Total water requirements per growth stage & 80.5 & 190.2 & 335.5 \\
\hline
\end{tabular}

The urea (46\%) at rate $120 \mathrm{~kg} \mathrm{~N} \mathrm{ha}^{-1}$, phosphoric acid (85\%) at rate $100 \mathrm{~kg} \mathrm{P}_{2} \mathrm{O}_{5} \mathrm{ha}^{-1}$ and potassium sulphate $(48.5 \%)$ at rate $100 \mathrm{~kg} \mathrm{~K}_{2} \mathrm{O} \mathrm{ha}{ }^{-1}$ biweekly fertigated in 24 equal doses, started in $2^{\text {nd }}$ week and continued until $14^{\text {th }}$ week . The fertilizers were injected directly into the irrigation water using a venture - type injector.

All agricultural practices were done as commonly followed in the commercial production of broccoli in the drip irrigation system. The average temperature and relative air humidity throughout broccoli growth stages at Hada-Alsham region conditions, Saudi Arabia are shown in Table 2.

Table 2. Average temperatures and humidity during the growing season of broccoli crop at Hada-Alsham region conditions, Saudi Arabia

\begin{tabular}{cccccccc}
\hline \multirow{2}{*}{ Month } & \multicolumn{3}{c}{ Temperature } & & \multicolumn{3}{c}{ Humidity } \\
\cline { 2 - 3 } \cline { 7 - 8 } \cline { 6 - 8 } & Min. & Max. & Mean & & Min. & Max. & Mean \\
\hline December & 18.7 & 30.5 & 24.4 & & 50.9 & 90.1 & 68.2 \\
January & 16.2 & 27.1 & 21.6 & & 57.9 & 93.7 & 73.0 \\
February & 19.0 & 31.0 & 24.8 & & 35.7 & 83.3 & 59.0 \\
March & 18.4 & 31.5 & 24.8 & & 29.9 & 73.1 & 50.5 \\
April & 21.7 & 36.3 & 28.9 & & 24.2 & 69.2 & 44.6 \\
\hline
\end{tabular}

\subsection{Data Recorded}

In each sub-plot, the first row was allocated to measuring the vegetative growth characters that included plant height, number of branches and leaves, and leaf area $\left(\mathrm{cm}^{2}\right)$, with initiation of main curd of $25 \%$ broccoli plants. 
The second row was saved to determine the main, secondary and total curds yield and its quality characters; curd diameter, curd weight and curd dry matter percentage. The leaf and curds contents of $\mathrm{N}, \mathrm{P}$ and $\mathrm{K}$ were estimated as described in Cottenie (1980). Water-use efficiency (WUE $\mathrm{kg} \mathrm{m}^{-3}$ ) was calculated by dividing total curds yield ( $\mathrm{kg}$ $\left.\mathrm{ha}^{-1}\right)$ of broccoli by total irrigation water applied $\left(6060.2 \mathrm{~m}^{3} \mathrm{ha}^{-1}\right)$ throughout the growing season.

\subsection{Statistical Analysis}

All obtained data of the present study were individually subjected to the analysis of variance techniques according to the design used by the MSTAT-C computer software program (Freed \& Scott, 1989). The comparisons among means of the different treatments were carried out by using the revised LSD test at $(\mathrm{P}<0.05)$.

\section{Results}

\subsection{Vegetative Growth}

Broccoli plants grown under saline water that receiving $\mathrm{K}^{+}$at concentration $1000 \mathrm{mg} \mathrm{l}^{-1}$ as foliar application were recorded minimum the deleterious impacts of salinity stress and achieved maximum plant height, number of leaves and branches, and leaf area per plant followed by plants receiving $500 \mathrm{mg} \mathrm{l}^{-1} \mathrm{~K}^{+}$and control treatments, respectively (Table 3).

Increasing the salicylic acid (SA) level up to $200 \mathrm{mg} \mathrm{l}^{-1}$ that was supplied as foliar and drench application lead to a significant progressive increasing in plant height, number of leaves and branches, and leaf area per plant over control treatment of broccoli plants irrigated with saline water.

The interaction effects of $\mathrm{K}^{+}$and SA concentrations on the vegetative growth traits of broccoli were significant (Table 3). Increasing the SA concentration up to $200 \mathrm{mg} \mathrm{l}^{-1}$ within any $\mathrm{K}+$ rate, generally, increased plant height, number of leaves and branches, and leaf area per plant. Spraying broccoli plants grown under salinity stress with $\mathrm{K}^{+}$at rate $1000 \mathrm{mg} \mathrm{l}^{-1}+\mathrm{SA}$ at rate $200 \mathrm{mg} \mathrm{l}^{-1}$ can be considered the best combined treatment, where achieved higher values of all studied vegetative growth characters.

Table 3. Effect of potassium and salicylic acid (SA) concentration and its interaction on the plant height, number of leaves and branches and leaf area of broccoli plants grown under saline water

\begin{tabular}{|c|c|c|c|c|c|}
\hline \multicolumn{2}{|c|}{ Treatments } & \multirow{2}{*}{ Plant height $(\mathrm{cm})$} & \multirow{2}{*}{ No. leaves/plant } & \multirow{2}{*}{ No. branches/plant } & \multirow{2}{*}{ Leaf area $\left(\mathrm{cm}^{2}\right)$} \\
\hline $\mathrm{K}_{2} \mathrm{O}(\mathrm{mg} / \mathrm{l})$ & $\mathrm{SA}(\mathrm{mg} / \mathrm{l})$ & & & & \\
\hline 0 & & $33.4 C^{*}$ & $20.1 \mathrm{C}$ & $6.9 \mathrm{C}$ & $455.41 \mathrm{C}$ \\
\hline 500 & & $36.1 \mathrm{~B}$ & 36.1B & $8.2 \mathrm{~B}$ & $532.84 \mathrm{~B}$ \\
\hline \multirow[t]{5}{*}{1000} & & $39.7 \mathrm{~A}$ & $39.7 \mathrm{~A}$ & $9.4 \mathrm{~A}$ & $579.73 \mathrm{~A}$ \\
\hline & 0 & $32.7 \mathrm{C}$ & 16.9B & $7.1 \mathrm{C}$ & $461.50 \mathrm{C}$ \\
\hline & 100 & $36.1 \mathrm{~B}$ & $19.1 \mathrm{~A}$ & $8.2 \mathrm{~B}$ & $541.22 \mathrm{~B}$ \\
\hline & 200 & $40.3 \mathrm{~A}$ & $21.7 \mathrm{~A}$ & $9.2 \mathrm{~A}$ & $565.26 \mathrm{~A}$ \\
\hline & 0 & $31.5 \mathrm{e}$ & $15.3 \mathrm{~g}$ & $6.3 \mathrm{e}$ & $367.86 \mathrm{i}$ \\
\hline \multirow[t]{3}{*}{0} & 100 & $33.7 \mathrm{~cd}$ & $21.3 \mathrm{f}$ & $7.2 \mathrm{de}$ & $477.84 \mathrm{~h}$ \\
\hline & 200 & $34.9 \mathrm{c}$ & $23.7 \mathrm{e}$ & $7.3 \mathrm{cde}$ & $520.53 \mathrm{f}$ \\
\hline & 0 & $32.9 \mathrm{de}$ & $21.2 \mathrm{f}$ & $7.5 \mathrm{cde}$ & $480.40 \mathrm{~g}$ \\
\hline \multirow[t]{3}{*}{500} & 100 & $34.8 \mathrm{c}$ & $25.4 \mathrm{~cd}$ & $8.1 \mathrm{bcd}$ & $551.80 \mathrm{~d}$ \\
\hline & 200 & $40.6 \mathrm{~b}$ & $26.1 b c$ & $8.9 b c$ & $566.31 \mathrm{c}$ \\
\hline & 0 & $33.8 \mathrm{~cd}$ & $24.2 \mathrm{de}$ & $7.6 \mathrm{~b}-\mathrm{e}$ & $536.24 \mathrm{e}$ \\
\hline \multirow[t]{2}{*}{1000} & 100 & $39.8 \mathrm{~b}$ & $27.4 \mathrm{ab}$ & $9.2 \mathrm{~b}$ & $594.02 \mathrm{~b}$ \\
\hline & 200 & $45.4 \mathrm{a}$ & $28.1 \mathrm{a}$ & $11.3 \mathrm{a}$ & 608.94a \\
\hline
\end{tabular}

*Values having the same alphabetical letter in common do not significantly differ at $\mathrm{P}<0.05$. 


\subsection{Curds Yield and Water Use Efficiency (WUE)}

Data of Table 4 illustrated that, increasing the spraying rate of $\mathrm{K}^{+}$up to $1000 \mathrm{mg}^{-1}$ significantly increased the main, secondary and total curds yield $\left(\mathrm{t} \mathrm{ha}^{-1}\right)$ by 59.7, 202.4 and 109.8\%, respectively, over the broccoli plants irrigated with saline water only (Table 4). Moreover, broccoli plants that treated with $1000 \mathrm{mg} \mathrm{l}^{-1}$ of $\mathrm{K}^{+}$achieved significantly higher WUS (109.8\%) over control treatment.

Table 4. Effect of potassium and salicylic acid (SA) concentration and its interaction on the number of main, secondary and total curds yield per hectare as well as the water use efficiency of broccoli plants grown under saline water

\begin{tabular}{|c|c|c|c|c|c|c|c|c|c|}
\hline \multicolumn{2}{|c|}{ Treatments } & \multirow{2}{*}{$\begin{array}{l}\text { Main curds } \\
\text { yield (t/ha) }\end{array}$} & \multirow{2}{*}{$\begin{array}{l}\text { Relative } \\
\text { value }\end{array}$} & \multirow{2}{*}{$\begin{array}{c}\text { Secondary } \\
\text { curds yield } \\
\text { (t/ha) }\end{array}$} & \multirow{2}{*}{$\begin{array}{c}\text { Relative } \\
\text { value }\end{array}$} & \multirow{2}{*}{$\begin{array}{l}\text { Total curds } \\
\text { yield ( } \mathrm{t} / \mathrm{ha})\end{array}$} & \multirow{2}{*}{$\begin{array}{l}\text { Relative } \\
\text { value }\end{array}$} & \multirow{2}{*}{$\begin{array}{c}\text { Water use } \\
\text { efficiency } \\
\left(\mathrm{kg} / \mathrm{m}^{3}\right)\end{array}$} & \multirow{2}{*}{$\begin{array}{c}\text { Relative } \\
\text { value }\end{array}$} \\
\hline $\mathrm{K}_{2} \mathrm{O}(\mathrm{mg} / \mathrm{l})$ & $\mathrm{SA}(\mathrm{mg} / \mathrm{l})$ & & & & & & & & \\
\hline 0 & & $4.62 \mathrm{C}^{*}$ & 100.00 & $2.51 \mathrm{C}$ & 100.00 & $7.13 \mathrm{C}$ & 100.00 & $1.18 \mathrm{C}$ & 100.0 \\
\hline 500 & & $6.67 \mathrm{~B}$ & 144.37 & $4.63 \mathrm{~B}$ & 184.46 & $11.30 \mathrm{~B}$ & 158.49 & $1.86 \mathrm{~B}$ & 157.6 \\
\hline \multirow[t]{5}{*}{1000} & & $7.38 \mathrm{~A}$ & 159.74 & $7.59 \mathrm{~A}$ & 302.39 & $14.96 \mathrm{~A}$ & 209.82 & $2.47 \mathrm{~A}$ & 209.3 \\
\hline & 0 & $5.07 \mathrm{~B}$ & 100.00 & $2.72 \mathrm{C}$ & 100.00 & $7.79 \mathrm{C}$ & 100.00 & $1.29 \mathrm{C}$ & 100.0 \\
\hline & 100 & $6.53 \mathrm{~A}$ & 128.80 & $5.17 \mathrm{~B}$ & 190.07 & $11.70 \mathrm{~B}$ & 150.19 & $1.93 \mathrm{~B}$ & 149.6 \\
\hline & 200 & 7.07A & 139.45 & $6.44 \mathrm{~A}$ & 236.76 & $13.50 \mathrm{~A}$ & 173.30 & $2.23 \mathrm{~A}$ & 172.9 \\
\hline & 0 & $4.23 \mathrm{~cd}$ & 100.00 & $1.39 \mathrm{f}$ & 100.00 & $5.61 \mathrm{~g}$ & 100.00 & $0.93 \mathrm{~g}$ & 100.0 \\
\hline \multirow[t]{3}{*}{0} & 100 & $4.70 \mathrm{c}$ & 111.11 & $3.03 \mathrm{e}$ & 217.99 & $7.74 \mathrm{f}$ & 137.97 & $1.28 \mathrm{f}$ & 137.6 \\
\hline & 200 & $4.93 \mathrm{c}$ & 116.55 & $3.34 \mathrm{e}$ & 240.29 & $8.27 \mathrm{f}$ & 147.42 & $1.36 \mathrm{f}$ & 146.2 \\
\hline & 0 & $4.89 \mathrm{c}$ & 115.60 & $3.12 \mathrm{e}$ & 224.46 & $8.00 \mathrm{f}$ & 142.60 & $1.32 \mathrm{f}$ & 141.9 \\
\hline \multirow[t]{3}{*}{500} & 100 & $7.30 \mathrm{ab}$ & 172.58 & $4.95 \mathrm{~cd}$ & 356.12 & $12.26 \mathrm{~d}$ & 218.54 & $2.02 \mathrm{~d}$ & 217.2 \\
\hline & 200 & $7.82 \mathrm{a}$ & 184.87 & $5.93 \mathrm{c}$ & 426.62 & $13.75 \mathrm{c}$ & 245.10 & $2.27 \mathrm{c}$ & 244.1 \\
\hline & 0 & $6.10 \mathrm{bc}$ & 144.21 & $3.98 \mathrm{de}$ & 286.33 & $10.08 \mathrm{e}$ & 179.68 & $1.66 \mathrm{e}$ & 178.5 \\
\hline \multirow[t]{2}{*}{1000} & 100 & $7.58 \mathrm{a}$ & 179.20 & $8.14 \mathrm{~b}$ & 585.61 & $15.72 \mathrm{~b}$ & 280.21 & $2.59 \mathrm{~b}$ & 278.5 \\
\hline & 200 & $8.45 \mathrm{a}$ & 199.76 & $11.11 \mathrm{a}$ & 799.28 & $19.55 \mathrm{a}$ & 348.48 & $3.23 \mathrm{a}$ & 347.3 \\
\hline
\end{tabular}

*Values having the same alphabetical letter in common do not significantly differ at $\mathrm{P}<0.05$.

Broccoli plants receiving SA at rate $200 \mathrm{mg} \mathrm{l}^{-1}$ recorded significantly higher the main, secondary and total curds yield $\left(\mathrm{t} \mathrm{ha}^{-1}\right)$ as well as WUE $\left(\mathrm{kg} \mathrm{m}^{-3}\right)$ with an increase of $39.5,136.8,73.3$ and $73.3 \%$, respectively, over the broccoli plants irrigated with saline only.

The interaction effects of the $\mathrm{K}^{+}$and SA concentrations on curds yield $\mathrm{ha}^{-1}$ and WUE of broccoli plants grown under salinity stress, showed much significantly variation (Table 4). Broccoli plants that sprayed with any $\mathrm{K}^{+}$ concentration, increasing foliar and drench application level of SA up to $200 \mathrm{mg} \mathrm{l}^{-1}$, led to increase the main, secondary and total curds yield $\left(\mathrm{tha}^{-1}\right)$ as well as WUE $\left(\mathrm{kg} \mathrm{m}^{-3}\right)$. Broccoli plants receiving $\mathrm{K}^{+}\left(1000 \mathrm{mg} \mathrm{l}^{-1}\right)+$ $200 \mathrm{mg} \mathrm{l}^{-1}$ of SA, gave the highest main, secondary and total curds yield $\left(\mathrm{t} \mathrm{ha}^{-1}\right)$ as well as WUE. The increases in main, secondary and total curds yield $\left(\mathrm{t} \mathrm{ha}^{-1}\right)$ as well as WUE were 99.7, 699.3, 248.5 and 247.3\%, respectively, over the control treatment.

\subsection{The Number of Curds and Curds Quality}

Foliar application of $\mathrm{K}^{+}$had a significant effect on the number of curds per plant and all recorded curds quality characteristics; curd diameter (of main and secondary), curd weight (of main, secondary and plant) and dry matter percentage of curds (Table 5). Increasing the concentration of $\mathrm{K}^{+}$up to $1000 \mathrm{mg}^{-1}$ was accompanied with corresponding significant increases in the number of curds per plant, curd diameter (of main and secondary), curd weight (of main, secondary and plant) and dry matter percentage of curds. 
Table 5. Effect of potassium and salicylic acid (SA) concentrations and its interaction on the number of curds per plant and curd quality characters of broccoli plants grown under saline water

\begin{tabular}{|c|c|c|c|c|c|c|c|c|}
\hline \multicolumn{2}{|c|}{ Treatments } & \multirow{2}{*}{ No. curds/plant } & \multicolumn{2}{|c|}{ Curd diameter $(\mathrm{cm})$} & \multicolumn{3}{|c|}{ Curd weight (g) } & \multirow{2}{*}{ Curd dry matter (\%) } \\
\hline $\mathrm{K}_{2} \mathrm{O}(\mathrm{mg} / \mathrm{l})$ & $\mathrm{SA}(\mathrm{mg} / \mathrm{l})$ & & Main & Second & Main & Second & /plant & \\
\hline 0 & & $4.2 \mathrm{C}^{*}$ & $16.2 \mathrm{C}$ & $8.9 \mathrm{C}$ & $230.9 \mathrm{C}$ & $39.6 \mathrm{C}$ & $356.3 \mathrm{C}$ & $9.93 \mathrm{C}$ \\
\hline 500 & & $5.4 \mathrm{~B}$ & 19.9B & $9.4 \mathrm{~B}$ & $333.6 \mathrm{~B}$ & $53.0 \mathrm{~B}$ & $564.9 \mathrm{~B}$ & $11.35 \mathrm{~B}$ \\
\hline \multirow[t]{5}{*}{1000} & & $6.8 \mathrm{~A}$ & $24.0 \mathrm{~A}$ & $13.7 \mathrm{~A}$ & $368.8 \mathrm{~A}$ & $65.8 \mathrm{~A}$ & $748.1 \mathrm{~A}$ & $12.48 \mathrm{~A}$ \\
\hline & 0 & $3.9 \mathrm{C}$ & $16.7 \mathrm{C}$ & $9.3 \mathrm{~B}$ & $253.6 \mathrm{C}$ & $47.4 \mathrm{C}$ & $389.4 \mathrm{C}$ & $9.91 \mathrm{C}$ \\
\hline & 100 & $5.8 \mathrm{~B}$ & $20.5 \mathrm{~B}$ & $10.8 \mathrm{~A}$ & $326.4 \mathrm{~B}$ & $53.8 \mathrm{~B}$ & $584.8 \mathrm{~B}$ & $11.46 \mathrm{~B}$ \\
\hline & 200 & $6.6 \mathrm{~A}$ & $22.9 \mathrm{~A}$ & $11.8 \mathrm{~A}$ & $353.3 \mathrm{~A}$ & $57.1 \mathrm{~A}$ & $675.1 \mathrm{~A}$ & $12.39 \mathrm{~A}$ \\
\hline & 0 & $3.2 \mathrm{e}$ & $12.4 \mathrm{~g}$ & $7.6 \mathrm{~d}$ & $211.3 \mathrm{~h}$ & $31.5 \mathrm{i}$ & $280.6 \mathrm{i}$ & $7.52 \mathrm{~g}$ \\
\hline \multirow[t]{3}{*}{0} & 100 & $4.6 \mathrm{cde}$ & $17.1 \mathrm{f}$ & $9.3 \mathrm{~cd}$ & $235.2 \mathrm{~g}$ & $42.1 \mathrm{~h}$ & $386.8 \mathrm{~h}$ & $10.44 \mathrm{f}$ \\
\hline & 200 & $4.7 \mathrm{cde}$ & $19.2 \mathrm{de}$ & $9.7 \mathrm{c}$ & $246.3 f$ & $45.2 \mathrm{~g}$ & $413.5 f$ & $11.82 \mathrm{~cd}$ \\
\hline & 0 & $4.1 \mathrm{de}$ & $17.7 \mathrm{ef}$ & $8.2 \mathrm{~cd}$ & $244.3 \mathrm{f}$ & $50.3 \mathrm{f}$ & $400.2 \mathrm{~g}$ & $10.47 \mathrm{f}$ \\
\hline \multirow[t]{3}{*}{500} & 100 & $5.7 \mathrm{bcd}$ & $19.7 \mathrm{~d}$ & $9.9 \mathrm{c}$ & $365.2 \mathrm{~d}$ & $52.7 \mathrm{e}$ & $612.9 \mathrm{~d}$ & $11.53 \mathrm{e}$ \\
\hline & 200 & $6.3 b c$ & $22.3 \mathrm{c}$ & $10.1 \mathrm{c}$ & $391.2 \mathrm{~b}$ & $55.9 \mathrm{~d}$ & $687.5 \mathrm{c}$ & $12.05 \mathrm{c}$ \\
\hline & 0 & $4.3 \mathrm{de}$ & $20.1 d$ & $12.1 \mathrm{~b}$ & $305.2 \mathrm{e}$ & $60.3 c$ & $504.2 \mathrm{e}$ & $11.75 \mathrm{de}$ \\
\hline \multirow[t]{2}{*}{1000} & 100 & $7.1 \mathrm{ab}$ & $24.8 \mathrm{~b}$ & $13.2 \mathrm{~b}$ & $378.9 \mathrm{c}$ & $66.7 \mathrm{~b}$ & $785.8 \mathrm{~b}$ & $12.39 \mathrm{~b}$ \\
\hline & 200 & $8.9 \mathrm{a}$ & $27.2 \mathrm{a}$ & $15.7 \mathrm{a}$ & $422.3 a$ & $70.3 \mathrm{a}$ & $977.7 \mathrm{a}$ & $13.30 \mathrm{a}$ \\
\hline
\end{tabular}

*Values having the same alphabetical letter in common do not significantly differ at $\mathrm{P}<0.05$.

Results in Table 5 indicated that SA could increase the number of curds and its quality characters of broccoli plants irrigated with saline water. Broccoli plants that sprayed and drenched by $200 \mathrm{mg} \mathrm{l}^{-1} \mathrm{SA}$ showed significantly increased the number of curds per plant, curd diameter (of main and secondary), curd weight (of main, secondary and plant) and dry matter percentage of curds by $69.2,37.1,26.9,39.3,20.5,73.4$ and $25.2 \%$ over the control treatment, respectively.

The comparisons among the means of the various combined treatments, presented in Table 5, clearly, demonstrated some significant interaction effects between $\mathrm{K}^{+}$and SA concentrations. Foliar application of $\mathrm{K}^{+}$at rate $1000 \mathrm{mg} \mathrm{l}^{-1}+200 \mathrm{mg} \mathrm{l}^{-1}$ of SA achieved the best results in lessening the injurious effects of salinity stress on broccoli plants. As these treatment has given the highest number of curds per plant (178.1\%), main and secondary curd diameter (119.4 and 106.6\%), curd weight of main, secondary and plant $(99.8,123.1$ and $248.4 \%)$ and curds dry matter percentage (76.9\%) of over control treatment.

\subsection{Leaf and Curd Mineral Contents}

Data in Table 6 showed that increase the foliar application of $\mathrm{K}^{+}$concentration up to $1000 \mathrm{mg} \mathrm{l}^{-1}$ was associated with a significant increase in the leaf and curd mineral contents (, $\mathrm{P}$ and $\mathrm{K} \%$ ) of broccoli plants compared with control plants irrigated with saline water only.

The leaf and curd mineral contents were significantly affected by application of SA (Table 6). The N, P and K percentages of broccoli leaf and curd grown under salinity stress tended to increased consistently and significantly with increase in the used SA concentration up to $200 \mathrm{mg} \mathrm{l}^{-1}$. 
Table 6. Effect of potassium and salicylic acid (SA) concentration and its interaction on leaf and curd mineral contents $(\mathrm{N}, \mathrm{P}, \mathrm{K})$ of broccoli plants grown under saline water

\begin{tabular}{|c|c|c|c|c|c|c|c|}
\hline \multicolumn{2}{|c|}{ Treatments } & \multicolumn{2}{|c|}{$\mathrm{N}(\%)$} & \multicolumn{2}{|c|}{$\mathrm{P}(\%)$} & \multicolumn{2}{|c|}{$\mathrm{K}(\%)$} \\
\hline $\mathrm{K}_{2} \mathrm{O}(\mathrm{mg} / \mathrm{l})$ & $\mathrm{SA}(\mathrm{mg} / \mathrm{l})$ & Leaf & Curd & Leaf & Curd & Leaf & Curd \\
\hline 0 & & $3.01 \mathrm{~B}$ & $4.89 \mathrm{~B}$ & $1.00 \mathrm{~B}$ & $2.11 \mathrm{C}$ & $2.60 \mathrm{~B}$ & $2.08 \mathrm{~B}$ \\
\hline 500 & & $3.15 \mathrm{~A}$ & $5.14 \mathrm{~A}$ & $1.20 \mathrm{~A}$ & $2.55 \mathrm{~B}$ & $2.70 \mathrm{~B}$ & $2.34 \mathrm{~A}$ \\
\hline 1000 & & $3.27 \mathrm{~A}$ & $5.21 \mathrm{~A}$ & $1.30 \mathrm{~A}$ & $2.81 \mathrm{~A}$ & $2.90 \mathrm{~A}$ & $2.50 \mathrm{~A}$ \\
\hline & 0 & $2.60 \mathrm{~B}$ & $4.66 \mathrm{C}$ & $0.63 \mathrm{~B}$ & $1.46 \mathrm{C}$ & $2.15 \mathrm{~B}$ & $1.88 \mathrm{~B}$ \\
\hline & 100 & $3.37 \mathrm{~A}$ & $5.09 \mathrm{~B}$ & $1.35 \mathrm{~A}$ & $2.81 \mathrm{~B}$ & $2.98 \mathrm{~A}$ & $2.30 \mathrm{~A}$ \\
\hline & 200 & $3.47 \mathrm{~A}$ & $5.49 \mathrm{~A}$ & $1.49 \mathrm{~A}$ & $3.20 \mathrm{~A}$ & $3.15 \mathrm{~A}$ & $2.74 \mathrm{~A}$ \\
\hline & 0 & $2.59 \mathrm{~d}$ & $4.66 \mathrm{c}$ & $0.51 \mathrm{e}$ & $0.57 \mathrm{~d}$ & $1.73 \mathrm{~d}$ & $1.69 \mathrm{e}$ \\
\hline 0 & 100 & $3.21 \mathrm{c}$ & $4.67 \mathrm{c}$ & $1.18 \mathrm{~d}$ & $2.67 \mathrm{~b}$ & $3.02 \mathrm{a}$ & $2.02 \mathrm{~d}$ \\
\hline & 200 & $3.23 \mathrm{c}$ & $5.33 b$ & $1.28 \mathrm{~cd}$ & $3.08 \mathrm{a}$ & $3.07 \mathrm{a}$ & $2.54 \mathrm{~b}$ \\
\hline & 0 & $2.59 \mathrm{~d}$ & $4.66 \mathrm{c}$ & $0.67 \mathrm{e}$ & $1.80 \mathrm{c}$ & $2.22 \mathrm{c}$ & $1.97 \mathrm{~d}$ \\
\hline 500 & 100 & $3.36 b c$ & $5.25 \mathrm{~b}$ & $1.33 \mathrm{bcd}$ & $2.67 \mathrm{~b}$ & $2.86 a b$ & $2.30 \mathrm{c}$ \\
\hline & 200 & $3.50 \mathrm{abc}$ & $5.51 \mathrm{ab}$ & $1.49 \mathrm{abc}$ & $3.18 \mathrm{a}$ & $3.15 \mathrm{a}$ & $2.74 \mathrm{ab}$ \\
\hline & 0 & $2.61 \mathrm{~d}$ & $4.67 \mathrm{c}$ & $0.72 \mathrm{e}$ & $2.01 \mathrm{c}$ & $2.50 \mathrm{bc}$ & $1.97 \mathrm{~d}$ \\
\hline 1000 & 100 & $3.53 \mathrm{ab}$ & $5.34 \mathrm{~b}$ & $1.54 \mathrm{ab}$ & $3.08 \mathrm{a}$ & $3.07 \mathrm{a}$ & $2.58 \mathrm{~b}$ \\
\hline & 200 & $3.68 \mathrm{a}$ & $5.62 \mathrm{a}$ & $1.69 \mathrm{a}$ & $3.34 \mathrm{a}$ & $3.23 \mathrm{a}$ & $2.94 \mathrm{a}$ \\
\hline
\end{tabular}

*Values having the same alphabetical letter in common do not significantly differ at $\mathrm{P}<0.05$.

The comparisons, presented in Table (6), illustrated the presence of some significant interaction effects, between $\mathrm{K}^{+}$and SA concentrations, on the leaf and curd mineral contents of broccoli plants grown under salinity stress. Generally, it was noticed that the highest leaf and curd mineral contents of broccoli plants were obtained from the treatment combination involving the with the foliar spraying with $\mathrm{K}+$ at rate $1000 \mathrm{mg}+200 \mathrm{mg} \mathrm{l}^{-1}$ of SA .

\section{Dissection}

The use of saline water in the irrigation vegetable crops under arid region conditions led to the gradual increase of salinity in roots zone of plants. The salinity suppresses the phosphorus $(\mathrm{P})$ uptake and reduces available $\mathrm{P}$ (Grattan \& Grieve, 1999) as well as $\mathrm{K}^{+}$and $\mathrm{Ca}^{2+}$ (Yildirim et al., 2006), causing a decrease in growth of the roots and plants, improving the management agricultural practices of broccoli production by using the $\mathrm{K}^{+}$as foliar application and salicylic acid (SA) as a drench and foliar application; will contribute to overcome the deleterious effect of salinity stress. Where, using $\mathrm{K}^{+}$as a foliar application led to regulating the desirable $\mathrm{K} / \mathrm{Na}$ ratio (Marschner, 1995). Moreover, SA is regulated of phenolic nature, which participates in the regulation of physiological processes in plants (Karlidag et al., 2009).

The results of this study showed that broccoli plants grown under saline water that receiving $\mathrm{K}^{+}$at concentration $1000 \mathrm{mg} \mathrm{l}^{-1}$ as foliar application were recorded minimum the deleterious impacts of salinity stress and achieved maximum plant height, number of leaves and branches, leaf area per plant, the main, secondary and total curd yield $\left(\mathrm{t} \mathrm{ha}^{-1}\right)$ and water use efficiency over control treatment. Furthermore, the curd diameter (of main and secondary), curd weight (of main, secondary and plant) dry matter percentage of the curds and the leaf and curd mineral contents (N, P and K\%) were improved with foliar application of $\mathrm{K}$ up to $1000 \mathrm{mg} \mathrm{l}^{-1}$. This can be explained based on $\mathrm{K}$ is an essential nutrient for plant growth and plays an important role in many metabolic processes (Khan \& Aziz, 2013) such as photosynthesis, use of water (Rose, 2001) and synthesis of amino acid and protein as well as translocation of sugars and assimilates within the plant and the accumulation of high molecular carbohydrates (Yagodin, 1982; Archer, 1985) necessary for fruit formation and development (Marschner, 1986) which leads to increase plant growth and yield. These results are in accordance with Yildirim et al. (2009) and Safaa et al. (2013). Hussein et al. (2012) they reported that foliar application of potassium mono 
phos-phate at $200 \mathrm{ppm}$ concentration increased the plant growth, biomass production, and fruit yield of pepper plants.

The vegetative growth, cruds yield and its quality, WUE and leaf and crud mineral contents of broccoli plants irrigated with saline water increased significantly and successively as the SA concentration was increased up to $200 \mathrm{mg} \mathrm{l}^{-1}$. This situation can be explained based on soil and foliar application of SA may be play a significant role in plant water relations (Barkosky \& Einhelling, 1993), photosynthesis, growth rate and stomatal regulation (Khan et al., 2003; Arfan et al., 2007), as well as ion uptake and transport (Gunes et al., 2005), membrane permeability (Barkosky and Einhellig, 1993), raising indoleacetic acid content and enhancing of cell division and extension of root cells (Shakirova et al., 2003). Gunes et al. (2006) illistrated that the increase in dry matter of salt stressed plants in response to SA might be related to the induction of antioxidant response and protective role of membranes that increase the tolerance of plant to damage or may be attributed to the increased mineral uptake by stressed plant with SA treatment (Yildirim et al., 2008). Similar results were reported by Yildirim et al. (2006) with cucumber, Lian et al. (2000) with soybean, Senaratna et al. (2000) and Stevens et al. (2006) with bean and tomato, where SA applications positively affected shoot and root growth parameters. Yildirim et al. (2008) reported that treated cucumber plants with SA as foliar applications resulted in greater shoot fresh weight, shoot dry weight, root fresh weight, and root dry weight as well as higher plants under salt stress.

\section{Conclusion}

The data obtained from the present study suggest that the combined foliar application of $1000 \mathrm{mg}^{-1} \mathrm{~K}+$ with salicylic acid at $200 \mathrm{mg} \mathrm{l}^{-1}$ as a dernch and foliar application is the most efficient combination treatment, which gave the best results to alleviate the deleterious impact of salinity stress on the vegetative growth, curd yield and its quality characters, leaf and curds chemical contents of broccoli plants irrigated with saline water.

\section{References}

Allen, R. G., Pereira, L. S., Raes, D., \& Smith, M. (1998). Crop Evapotranspiration-Guidelines for Computing Crop Water Requirements (pp. 104-114). FAO Irrigation and drainage paper No. 56. FAO Rome, Italy.

Archer, J. (1985). Crop nutrition and fertilizer use (p. 258). Farming Press Ltd.

Arfan, M., Athar, H. R., \& Ashraf, M. (2007). Does exogenous application of salicylic acid through the rooting medium modulate growth and photosynthetic capacity in two differently adapted spring wheat cultivars under salt stress? Journal of Plant Physiology, 164, 685-694. http://dx.doi.org/10.1016/j.jplph.2006.05.010

Ayers, R. S., \& Westcot, D. W. (1994). Water quality for agriculture, salinity problems. Retrieved from http://www.fao.org/DOCREP/003/T0234E/T0234E00.htm\#TOC

Barkosky, R. R., \& Einhellig, F. A. (1993). Effects of salicylic acid on plant water relationship. J. Chem. Ecol., 19, 237-247. http://dx.doi.org/10.1007/BF00993692

Beecher, C. (1994). Cancer preventive properties of varieties of Brassica aleracea: A review. Am. J. Clin. Nutr., 59, 116-1170.

Bhandal, I. S., \& Malik, C. P. (1988). Potassium estimation, uptake, and its role in the physiology and metabolism of flowering plants. International Review of Cytology, 110, 205-254. http://dx.doi.org/10.1016/S0074-7696(08)61851-3

Cottenie, A. (1980). Soil and Plant Testing as a Basis of Fertilizer Recommendations (pp. 55-60). FAO soil Bulletin. Soil Resources, Management and Conservation Service No. 38/2. FAO Rome, Italy.

El-Fouly, M. M., Mobarak, Z. M., \& Salama, Z. A. (2002). Micronutrient foliar application increases salt tolerance of tomato seedlings. Acta Horticulturae, 573, 467-474.

EL-Tayeb, M. A. (2005). Response of barley grains to the interactive effect of salinity and salicylic acid. Plant Growth Regulation, 45, 215-224. http://dx.doi.org/10.1007/s10725-005-4928-1

Evans, H. J., \& Sorger, G. J. (1996). Role of mineral elements with emphasis on the univalent cations. Ann. Rev. Plant Physio., 17, 47-76. http://dx.doi.org/10.1146/annurev.pp.17.060166.000403

Farahbakhsh, H., \& Shamsaddin Saiid, M. (2011). Effects of foliar application of salicylic acid on vegetative growth of maize under saline conditions. Afr. J. Plant Sci., 5, 575-578.

Fathy, M. F., Abdel-Motagally, I., \& Kamal, K. A. (2009). Response of Sugar Beet Plants to Nitrogen and Potassium Fertilization in Sandy Calcareous Soil. Int. J. Agric. \& Biol., 11, 695-700.

Feher, P. K. (1986). The role of broccoli in nutrition. Hort. Abs., 56(12), 1030. 
Freed, R. D., \& Scott, E. (1989). MSTAT-C. A Software Package for the Design, Management, and Analysis of Agronomic Experiments. Michigan State University, USA.

Gad, N. (2005). Interactive effect of salinity and cobalt on tomato plants II-Some physiological parameters as affected by Cobalt and Salinity. Res. J. Agric. Biolog. Sci., 1, 270-276.

Gad, N., \& Abd El-Moez, M. R. (2011). Broccoli growth, yield quantity and quality as affected by cobalt nutrition. Agric. Biol. J. N. Am., 2, 226-231. http://dx.doi.org/10.5251/abjna.2011.2.2.226.231

Grattan, S. R., \& Grieve, C. M. (1999). Mineral nutrient acquisition and response by plants grown in saline environments. In M. Pessarakli (Ed.), Handbook of Plant and Crop Stress (pp. 203-213). Marcel Dekker, New York, USA.

Gunes, A., Inal, A., Alpaslan, M., Cicek, N., Guneri, E., Eraslan, F., \& Guzelordu, T. (2005). Effects of exogenously applied salicylic acid on the induction of multiple stress tolerance and mineral nutrition in maize (Zea mays L.). Archives of Agronomy and Soil Science, 51, 687-695. http://dx.doi.org/10.1080/03650340500336075

Halperin, S. T., Gilroy, S., \& Lynch, J. P. (2003). Sodium chloride reduces growth and cytosolic calcium, but does not affect cytosolic pH, in root hairs of Arabidopsis thaliana L. J. Exp. Bot., 54, 1269-1280. http://dx.doi.org/10.1093/jxb/erg134

Hussain, K., Nawaz, K., Majeed, A., Ilyas, U., Lin, F., Ali, K., \& Nisar, M. F. (2011). Role of exogenous salicylic acid applications for salt tolerance in violet (Viola Odorata L.). Sarhad J. Agric., 27, 171-175.

Hussein, M. M., El-Faham, S. Y., \& Alva, A. K. (2012). Pepper plants growth, yield, photosynthetic pigments, and total phenols as affected by foliar application of potassium under different salinity irrigation water. Agricultural Sciences, 3, 241-248. http://dx.doi.org/10.4236/as.2012.32028

Kang, H. M., \& Saltveit, M. E. (2002). Chilling tolerance of maize, cucumber and rice seedling leaves and roots are differentially affected by salicylic acid. Physiol. Plant, 115, 571-576. http://dx.doi.org/10.1034/j.1399-3054.2002.1150411.x

Karlidag, H., Yildirim, E., \& Turan, M. (2009). Exogenous applications of salicylic acid affect quality and yield of strawberry grown under antifrost heated greenhouse conditions. J. Plant Nutr. Soil Sci., 172, 270-276. http://dx.doi.org/10.1002/jpln.200800058

Keren, R. (2000). Salinity. In M. E. Sumner (Ed.), Handbook of Soil Science (pp. G3-G25). Boca Raton: CRC Press.

Khan, A., \& Aziz, M. (2013) Influence of foliar application of potassium on wheat (Triticum aestivum) under saline conditions. Sci. Tech. and Dev., 32, 285-289.

Khan, A., Shaheen, Z., \& Nawaz, M. (2013). Amelioration of salt stress in wheat (Triricum aestivum L.) by foliar application of nitrogen and potassium. Sci., Tech. and Dev., 32(2), 85-98.

Khan, W., Prithiviraj, B., \& Smith, D. L. (2003). Photosynthetic responses of corn and soybean to foliar application of salicylates. J. Plant Physiol., 160, 485-492. http://dx.doi.org/10.1078/0176-1617-00865

Lian, B., Zhou, X., Miransari, M., \& Smith, D. L. (2000). Effects of salicylic acid on the development and root nodulation of soybean seedlings. J. Agronomy Crop Science, 185, 187-192. http://dx.doi.org/10.1046/j.1439-037x.2000.00419.x

Marschner, H. (1986). Mineral Nutrition of Higher Plants (pp. 514-515). London: Academic Press.

Marschner, H. (1995). Mineral nutrition of higher plants (2nd ed., p. 864). Acad Press Limited, Text Book.

Michaud, D. S., Pietnen, P., Taylor, R. R., Virtanen, M., Vitramo, J., \& Albanes, D. (2002). Intakes of fruits and vegetables, carotenoids and vitaminsA, E, C in relation to the risk of bladder cancer in the ATBC cohort study. Br. J. Cancer, 87, 960-965. http://dx.doi.org/10.1038/sj.bjc.6600604

Morelock, T. E., Peerson, M., \& Motes, D. (1982). Broccoli trials in Arkansas. Arkansas Farm Research, 1(31), 12-13.

Page, A. L., Miller, R. H., \& Reeney, D. R. (1982). Methods of Soil Analysis (Part 2). ASA, SSSA, Madison, Wisconsin, USA.

Qassim, A., \& Ashcroft, B. (2002). Estimating vegetable crop water use with moisture-accounting method \# AG1192, DPI Victoria. Retrieved October, 2002, from 
http://www.dpi.vic.gov.au/agriculture/horticulture/vegetables/vegetable-growing-and-management/estimati ng-vegetable-crop-water-use

Raskin, I. (1992). Role of salicylic acid in plants. Annu. Rev. Plant Physiol. Plant Mol. Biol., 43, $439-463$. http://dx.doi.org/10.1146/annurev.pp.43.060192.002255

Ross, M. K. (2001). Potassium as fertilizer for plants. J. Plant Nutr., 425-433.

Safaa, R., El, L., Magdi, T., Abde, H., \& Fatma, R. (2013). Effect of Potassium Application on Wheat (Triticum aestivum L.) Cultivars grown under salinity stress. World Applied Sciences Journal, 26(7), 840-850.

Salehi, S., Khajehzadeh, A., \& Khorsandi, F. (2011). Growth of Tomato as Affected by Foliar Application of Salicylic Acid and Salinity. American-Eurasian J. Agric. \& Environ. Sci., 11(4), 564-567.

Senaratna, T., Touchell, D., Bunn, E., \& Dixon, K. (2000). Acetyl salicylic acid (Aspirin) and salicylic acid induce multiple stress tolerance in bean and tomato plants. Plant Growth Regulation, 30, 157-161. http://dx.doi.org/10.1023/A:1006386800974

Shi, Q., Bao, Z., Zhu, Z., Ying, Q., \& Qian, Q. (2006). Effects of different treatments of salicylic acid on heat tolerance, chlorophyll fluorescence, and antioxidant enzyme activity in seedlings of Cucumis sativa L. Plant Growth Regulation, 48, 127-135. http:/dx.doi.org/10.1007/s10725-005-5482-6

Singh, B., \& Usha, K. (2003). Salicylic acid induced physiological and biochemical changes in wheat seedlings under water stress. Plant Growth Regulation, 39, 137-141. http://dx.doi.org/10.1023/A:1022556103536

Stevens, J., Senaratna, T., \& Sivasithamparam, K. (2006). Salicylic acid induces salinity tolerance in tomato (Lycopersicon esculentum cv. Roma): Associated changes in gas exchange, water relations and membrane stabilisation. Plant Growth Regulation, 49, 77-83.

Yagodin, B. A. (1982). Agricultural chemistry. Mir. Publishers. PP. 375. Moscow.

Yamaguchi, T., \& Blumwald, E. (2005) Developing salt-tolerant crop plants: Challenges and opportunities. Trends Plant Sci, 10(12), 616-619. http://dx.doi.org/10.1016/j.tplants.2005.10.002

Yildirim, E., Karlidag, H., \& Turan, M. (2009). Mitigation of salt stress in strawberry by foliar K, Ca and Mg nutrient supply. Plant Soil Environ., 55(5), 213-221.

Yildirim, E., Taylor, A. G., \& Spittler, T. D. (2006). Ameliorative effects of biological treatments on growth of squash plants under salt stress. Scientia Horticulturae, 111, 1-6. http://dx.doi.org/10.1016/j.scienta.2006.08.003

Yildirim, E., Turan, M., \& Guvenc, I. (2008). Effect of foliar salicylic acid applications on growth, chlorophyll, and mineral content of cucumber grown under salt stress. Journal of Plant Nutrition, 31, $593-612$. http://dx.doi.org/10.1080/01904160801895118

\section{Copyrights}

Copyright for this article is retained by the author(s), with first publication rights granted to the journal.

This is an open-access article distributed under the terms and conditions of the Creative Commons Attribution license (http://creativecommons.org/licenses/by/3.0/). 